\title{
Mountain Ecosystems as Natural Laboratories for Climate Change Experiments
}

OPEN ACCESS

Edited by:

Sophie Fauset,

University of Plymouth,

United Kingdom

Reviewed by:

Giuliano Maselli Locosselli,

University of São Paulo, Brazil

Simone Aparecida Vieira,

Campinas State University, Brazil

*Correspondence:

Richard Tito

rtitoleon@gmail.com

Kenneth J. Feeley

kjfeeley@gmail.com

Specialty section:

This article was submitted to

Tropical Forests,

a section of the journal

Frontiers in Forests and Global

Change

Received: 23 October 2019

Accepted: 13 March 2020

Published: 31 March 2020

Citation:

Tito $R$, Vasconcelos $H L$ and

Feeley KJ (2020) Mountain

Ecosystems as Natural Laboratories

for Climate Change Experiments.

Front. For. Glob. Change 3:38.

doi: 10.3389/ffgc.2020.00038

\begin{abstract}
Richard Tito ${ }^{1,2,3 *}$, Heraldo L. Vasconcelos ${ }^{2}$ and Kenneth J. Feeley ${ }^{1 *}$
${ }^{1}$ Department of Biology, University of Miami, Coral Gables, FL, United States, ${ }^{2}$ Instituto de Biologia, Universidade Federal de Uberlândia, Uberlândia, Brazil, ${ }^{3}$ Instituto de Ciencias de la Naturaleza, Territorio y Energías Renovables, Pontificia Universidad Católica del Perú, Lima, Peru
\end{abstract}

Experimental studies are needed to empirically examine the effects of climate change on terrestrial organisms and to serve as the basis for predictions and management practices. As such, designing and implementing experimental systems that can simulate complex changes in the natural environment is currently a major area of interest of climate change science. Most climate change experiments (e.g., infrared heaters, open-top chambers) are typically performed within small, controlled environments and often manipulate just temperature and/or $\mathrm{CO}_{2}$ concentration. Other factors are more difficult to control (e.g., wind speed, soil moisture) or are frequently ignored (e.g., biotic interactions), leading to uncertainties in the results and limiting our ability to make realistic predictions about species' responses to future environmental changes. We examined the natural variation of abiotic and biotic factors along mountain elevational gradients in order to highlight the potential for using these systems as natural laboratories for climate change research and experiments. The high variability of different abiotic and biotic factors along elevational gradients provides a good opportunity to carry out field transplant/translocation experiments aimed at answering some critical questions, including: How will new biotic assemblages affect key interactions and processes? What are the factors that influence species assemblages under novel climates? How do local abiotic factors influence the establishment of species migrating into novel and climatically suitable habitats? Based on empirical evidence, we strongly encourage researchers to take advantage of the natural environmental gradients found in mountains to study the potential direct and indirect impacts of climate change on species, communities and biodiversity as a whole.

\section{Keywords: altitudinal gradients, common garden experiments, experimental warming, field experiments, global warming, latitudinal gradients, novel interactions, transplant experiments}

\section{INTRODUCTION}

As the global climate continues to change and the effects of these changes become more pronounced, we need to prioritize studies that can provide a solid understanding of how complex environmental changes will directly and indirectly impact ecological processes. Experimental studies are critical for empirically examining the effects of climate change on terrestrial systems and organisms, and these studies may serve as the basis for many predictions and management 
practices. However, designing and implementing experiments that can fully simulate multifactorial changes in the natural environment remains a daunting problem.

Most climate change experiments have been carried out in controlled environments. Heating experiments such as infrared heaters, open-top chambers, soil heating cables or glasshouses are typically employed over small spatial scales and often manipulate just temperature and/or $\mathrm{CO}_{2}$ concentrations (Bokhorst et al., 2011; Pelini et al., 2011; Elmendorf et al., 2015; Kimball, 2016; Wang et al., 2017). Although a specific variable(s) of interest can be controlled in this type of experiments, other factors are more difficult to control (e.g., wind speed, radiation, relative air humidity, soil moisture content). In addition, simulating changes in some factors, such as biotic interactions, may be difficult or impossible within laboratory or mesocosm experiments. Several recent studies have highlighted the limitations in the results from controlled experiments that can arise due to these and other problems. For example, a large-scale comparative analysis (for 1,634 plant species) of warming experiments and observational studies concluded that heating experiments underestimate the effects of climate change on plant phenological responses (Wolkovich et al., 2012) - although a subsequent analysis suggested that this is not always true for tundra species (Elmendorf et al., 2015). Likewise, Yang et al. (2018) compared three different methods (transplants, open top chamber and field long-term monitoring) and showed that the influence of altered competition under warmer conditions was only detected in the transplant experiments. Another recent study (Ettinger et al., 2019) evaluated the alteration of microclimates within experimental warming plots (15 studies) and showed that heating experiments produce changes in soil conditions (soil drying) that can have important biological consequences, but that this indirect effect of warming was often overlooked. These limitations decrease our ability to predict species' responses to climate change, and consequently our capability to plan and effectively implement conservation actions (Pressey et al., 2007; Reside et al., 2018; Ettinger et al., 2019).

Conducting experiments within natural environments is one promising option for more realistic assessments of how species and communities will respond to climate change. There is a growing number of studies taking advantage of natural environmental gradients - including latitudinal (Frenne et al., 2013; Nooten and Hughes, 2014; Nooten et al., 2014), elevational (Alexander et al., 2015; Tito et al., 2018), geothermal (Valdés et al., 2018) or forest successional gradients (Agosta et al., 2017) - in climate change studies. The use of elevational gradients can be an especially powerful and logistically feasible tool for studying how climate and other factors influence species' distributions and physiologies (Malhi et al., 2010; Silveira et al., 2019). Field experiments using elevational gradients can reveal effects that cannot be easily detected with experiments in controlled or artificial settings (Alexander et al., 2015; Nooten and Hughes, 2017; Tito Leon, 2017; Tito et al., 2018).

One of the most important advantages of field experiments is the possibility of detecting changes in biotic interactions and their effects (Alexander et al., 2015; Nooten and Hughes, 2017; Tito et al., 2018). There is a broad consensus that climate change will modify ecological communities by driving some species locally extinct and/or by creating new assemblages among species whose ranges did not previously overlap (Hobbs et al., 2006; Lavergne et al., 2010; Lurgi et al., 2012). Indeed, some field experiments have shown that the indirect effects of altered interactions are the most important drivers of plant responses to climate change (Alexander et al., 2015; Tito et al., 2018). However, despite the clear need to understand how the combined direct and indirect effects of climate change will affect species assemblages, field studies that allow for altered biotic interactions remain scarce. Revising more than half a million studies that focused on the possible impacts of climate change on terrestrial organisms, Nooten and Hughes (2017) found only 47 that were based on field experiments.

Here, we present a brief analysis of the natural variation of abiotic and biotic factors along mountain elevation gradients in order to highlight the potential for using these systems in climate change studies. Many of the ideas presented here are based on a set of field experiments conducted along an elevation gradient in the Peruvian tropical Andes (Tito Leon, 2017; Tito et al., 2018). Our goal in presenting this perspective article is to encourage the use of field experiments in future studies focused on determining the direct and indirect effects of climate change.

\section{ENVIRONMENTAL VARIATION ALONG MONTANE ELEVATIONAL GRADIENTS}

During last few decades, there were many efforts to define mountainous areas and to map the occurrence of these areas globally (Kapos et al., 2000; Körner et al., 2011, 2017; Elsen and Tingley, 2015; Antonelli et al., 2018; Price et al., 2019). The resulting classification system, which has been employed in many studies (Elsen and Tingley, 2015; Price et al., 2019), is based on elevation ( $>300 \mathrm{~m}$ asl) and ruggedness criteria, and indicates that mountain areas occupy approximately 21$24 \%$ of the global land area (Kapos et al., 2000; Meybeck et al., 2001). However, because the criteria previously used to define mountain areas allowed the inclusion of areas (e.g., plateaus, hilly lowland terrain) that seem inappropriate in a mountain biodiversity context, the methodology was improved and refined by applying a finer spatial resolution and considering local elevation range (maximal elevation difference among neighboring grid points: $200 \mathrm{~m}$ across $3 \times 3$ grid points of 30" within each grid cell; see Körner et al., 2011 for more detail) (Körner et al., 2011, 2017; Price et al., 2019). Using this new approach, it is now acknowledged that mountainous regions represent $\sim 12 \%$ of the Earth's terrestrial land surface outside of Antarctica (Körner et al., 2011, 2017). One of the most outstanding characteristics of mountainous regions is the high altitudinal variability of many climatic and non-climatic factors (Körner, 2007; Rapp and Silman, 2012). The high heterogeneity of abiotic conditions over short spatial scales is also reflected in the elevational variation of the diversity and composition of many montane plant and animal communities (Körner, 2007; Farfan-Rios et al., 2015). As a consequence, mountain regions host especially high levels of diversity and 
endemism (Barthlott et al., 1996; Myers et al., 2000; Körner, 2004; Rahbek et al., 2019b).

\section{Abiotic Factors}

Although the topography of mountains changes considerably from one region to another, there is a universal and steady decrease in mean air temperatures as elevation increases (Körner, 2007; Kessler et al., 2011; Rapp and Silman, 2012; Figure 1A). However, the rate that temperature decreases with elevation can vary depending on the slope and location of the mountain. For instance, along an elevation gradient in the southeastern slope of the Peruvian Andes, temperature decreases with an adiabatic lapse rate of approximately $5.2^{\circ} \mathrm{C}$ for every $1,000 \mathrm{~m}$ of elevation (Rapp, 2010), while on a southwestern Andean slope temperature decreases at a rate of $7.4^{\circ} \mathrm{C}$ per $1,000 \mathrm{~m}$ (Tito et al., 2018). Nonetheless, the temporal variation in temperature follows similar patterns on both the eastern (Rapp and Silman, 2012) and western slopes of the Andes (Tito et al., 2018). Several other studies also report an adiabatic decrease in temperature with elevation. For example, Kessler et al. (2011) show elevational temperature decrease for 20 other tropical and temperate regions.

Soil physical and chemical properties usually vary within mountain ranges and there is no consistency in patterns between mountain areas (Körner, 2007; Rahbek et al., 2019a). The heterogeneity of soil properties along mountain slopes depends on local characteristics such as topography, vegetation and geographic location. For example, soil organic matter increases with elevation in the Peruvian Andes (Zimmermann et al., 2010; Tito et al., 2018), in the mountains of Hawaii (Townsend et al., 1995), and in Mt. Rainier in the western United States (Zimmermann et al., 2010; Ettinger and Hillerislambers, 2017). In contrast, in the Himalayas, soil organic matter decreases at higher elevations (Sheikh et al., 2009). In the southwestern Peruvian Andes, high concentrations of phosphorus and potassium are found at middle elevations ( $\sim 3,500 \mathrm{~m}$ asl), whereas calcium content increases and magnesium content decreases strongly with elevation (Tito et al., 2018). Nitrogen and phosphorus content show no trend with elevation on Mt. Rainier (Ettinger and Hillerislambers, 2017) and on the arid Tianshan Mountain in northwest China (Xu et al., 2019). In the Andes, nitrogen content decreases with elevation and is limiting for plants at high elevations (Zimmermann et al., 2010). Studies argue that many tropical mountain soils are younger and more nitrogen-limited at high elevations, and that soils are older and more phosphoruslimited at low elevations (Vitousek and Sanford, 1986; Vitousek and Farrington, 1997). In short, the existing studies indicate that soil properties vary strongly with elevation (but not necessarily in the same way in different regions) and that future studies on species' responses to climate change should take this into account.

Precipitation, relative humidity, and solar radiation are other important abiotic factors that vary in mountains, but without unidirectional elevational trends (Körner, 2007). For example, photosynthetically active radiation (PAR) on $\mathrm{Mt}$. Rainier increases with elevation (Ettinger and Hillerislambers, 2017); in contrast, in tropical montane cloud forests, PAR decreases with elevation due to increased cloud cover and cloud immersion (Rapp and Silman, 2012). There is no general pattern for precipitation changes in relation to elevation (Körner, 2007). In some mountains (e.g., in the southern Peruvian Andes) the elevational variation in precipitation is not significant due to steep slopes and rapid changes in elevation over very small spatial scales (Condom et al., 2011). Humidity increases with elevation in some mountains (e.g., in the western United States) (Körner, 2007; Ettinger and Hillerislambers, 2017) but decreases with elevation in others (e.g., eastern of Neotropical Andes)

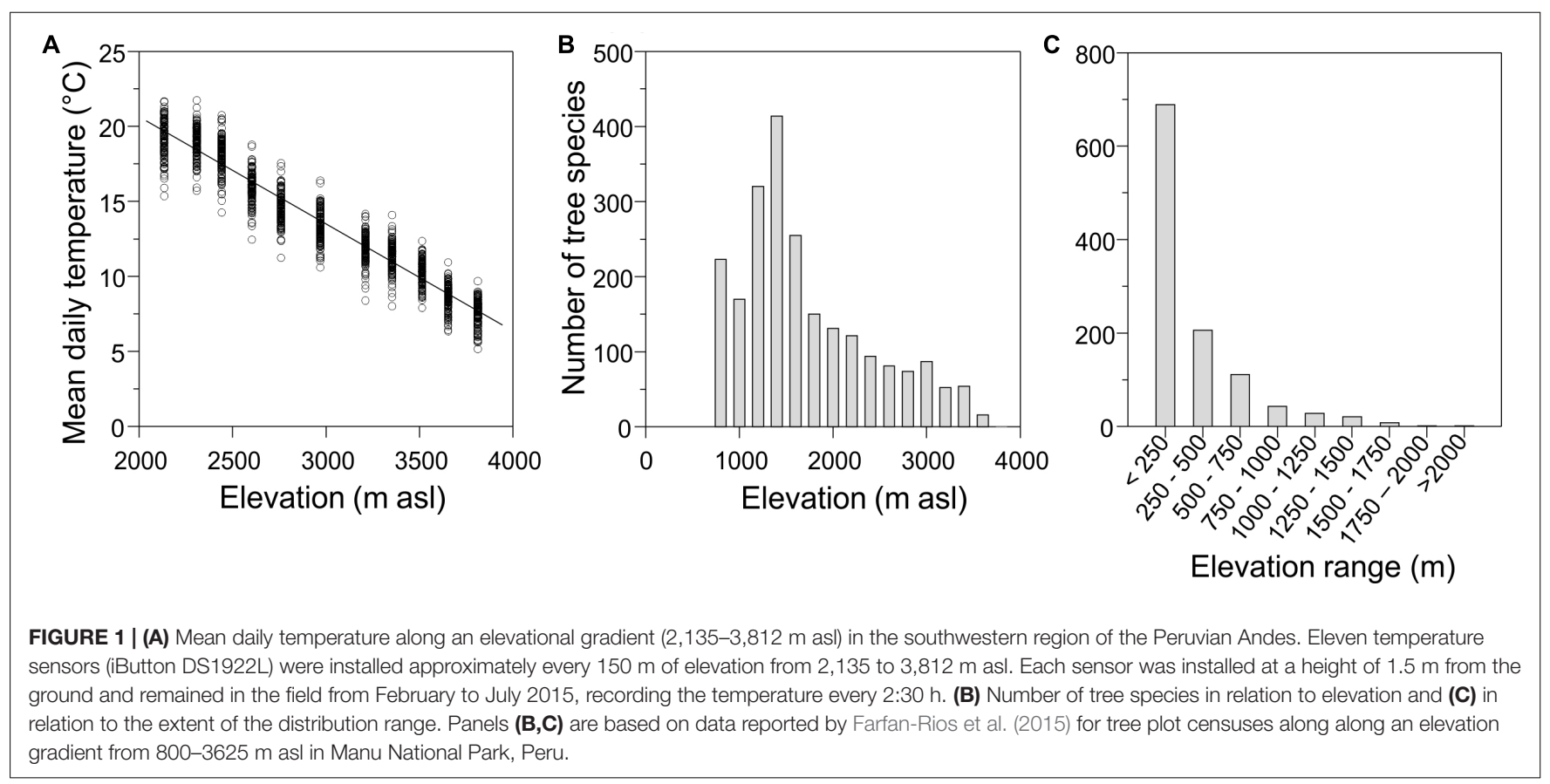


(Rapp and Silman, 2012) and is greatest at mid-elevations in others (e.g., Mount Kilimanjaro) (Körner, 2007). Because of their low temperatures, high elevations are generally more susceptible to frost, snow and hail.

\section{Current Variation in Biotic Factors}

There are elevated levels of species richness and endemicity in most mountain regions, and thus these systems are clear priority areas for conservation (Myers et al., 2000; Körner, 2004, 2007; Rahbek et al., 2019b). While covering just $12 \%$ of the land surface, mountains host more than $85 \%$ of the world's bird, amphibian and mammal species (Körner et al., 2011; Rahbek et al., 2019b), and at least one third of the terrestrial plant species (Barthlott et al., 1996; Körner, 2004, 2007). Most montane species have narrow elevational ranges (Rahbek et al., 2019b; Figure 1C).

Richness, composition and structure of plant and animal communities change along elevational gradients. Farfan-Rios et al. (2015) recorded over 1,000 species of trees, palms and lianas along an elevation gradient of $\sim 2,800 \mathrm{~m}$, from submontane forests at $800 \mathrm{~m}$ asl up to the tree line at 3,625 $\mathrm{m}$ asl in Manu National Park, Peru. From the distributional ranges reported in this study, we observe that plant species richness generally decreases with elevation but has a marked peak at $\sim 1,400 \mathrm{~m}$ asl (Figure 1B), consistent with previous studies (Rahbek, 1995; Girardin et al., 2010).

Similar to the elevational variation of plant species richness, the diversity of herbivores (Hodkinson, 2005; Metcalfe et al., 2014; Rasmann et al., 2014; but see Galmán et al., 2018), frugivorous birds (Dehling et al., 2014; Bender et al., 2019), seed predators (Hargreaves et al., 2019), and soil bacteria and fungi (Nottingham et al., 2018) also decreases with elevation. In the case of geometrid moths (Beck et al., 2017), salamanders (McCain and Sanders, 2010), tropical ferns (Kessler et al., 2011) and non-volant small mammals (McCain, 2005), mid-elevational peaks in species richness are reported, but with sharp declines in richness at higher elevations. These elevational patterns of species richness and abundance can cause changes in the biotic pressures that local populations endure at different elevations within their ranges. For example, studies show that herbivory (Metcalfe et al., 2014), seed predation (Hargreaves et al., 2019), and predation rates on model caterpillars (Roslin et al., 2017) are greater at lower elevations. In addition, immigrant lowland plant species are expected to have increased competitive abilities (Yang et al., 2018). It is generally hypothesized that biotic interactions (e.g., competition, herbivory) set the lower limit of species' elevational ranges while harsh climatic conditions set species' upper elevational range limits (Ettinger et al., 2011; Hillerislambers et al., 2013).

\section{PREDICTED SPECIES RESPONSE AND FUTURE RESEARCH DIRECTIONS}

Many plant and animal species are migrating to higher elevations and latitudes in response to ongoing changes in climate (e.g., Chen et al., 2011; Feeley et al., 2011b; Lenoir and Svenning, 2015; MacLean and Beissinger, 2017; Fadrique et al., 2018;
Freeman et al., 2018). However, studies suggest that migration rates are commonly slower than the rates required to track concurrent warming (Feeley et al., 2011a; Fadrique et al., 2018). Furthermore, several species appear unable to migrate due to different biological (e.g., dispersal capacity) or geographical (e.g., area availability) barriers (Hobbs et al., 2006; Rehm and Feeley, 2015, 2016; Alexander et al., 2018). However, several species may not need to migrate and may be able to persist under altered climates due to phenotypic plasticity and acclimation (MacLean and Beissinger, 2017). Overall, species vary widely in both their ability to change their geographic distributions due to climate change, but additional work is required to develop a more detailed understanding of climate-driven range shifts. For example, phytophagous insects are mobile organisms and can "migrate" faster than their associated host plants (Berg et al., 2010). Therefore, in this system, asynchronous species migrations could eventually lead to disrupted or reorganized interaction networks (Figure 2B).

In this context, several fundamental questions remain unanswered, including: How will new biotic assemblages affect key interactions and processes? What are the factors that influence species assemblages under altered climates? And, how do local abiotic factors (e.g., new soil conditions) influence the establishment of species migrating into novel and climatically suitable habitats? (Ibañez et al., 2006). The pronounced elevation and temperature gradients in mountains offer an ideal natural system to carry out field experiments aimed at answering these and other critical questions. Downslope translocation and transplant experiments can simulate future scenarios of climate change in the natural environment and can be used to determine the potential direct and indirect impacts of global warming on individuals, populations and communities. We summarize below some of the field transplant experiments that have used natural environmental gradients to simulate future conditions.

In order to assess the impacts of natural enemies (herbivores and pathogens) that can occur under future warming on potato and maize varieties in the Andes, Tito et al. (2018) used downslope transplants of seeds and tubers (with their home soil) to warmer areas $\left(+1.3\right.$ and $\left.+2.6^{\circ} \mathrm{C}\right)$. This experiment revealed that the survival and productivity of both potato and maize varieties under warmer climates was strongly affected by novel pest and diseases. Other studies using latitudinal gradients have likewise shown that warming can lead to new suites of herbivore species colonizing the host plants (Nooten et al., 2014) and cause increased damage in some species (Nooten and Hughes, 2014). Beyond the obvious need for similar studies in more species and systems, these transplant studies reveal some new hypotheses that need to be addressed. For example, generalist interactions among species will likely be less constrained by the identity of the host plants (Dunn et al., 2009; Lurgi et al., 2012), while specialist enemies or mutualists with obligate interactions may be limited to asynchronous migration with their host plants (Dunn et al., 2009; Lurgi et al., 2012). Theoretical studies suggest that the risk of species extinctions consequently increases with the level of specialization (Binzer et al., 2011; Lurgi et al., 2012). Furthermore, warming also likely influences the phenology of insects and their host plants and may lead to temporal mismatches between species 

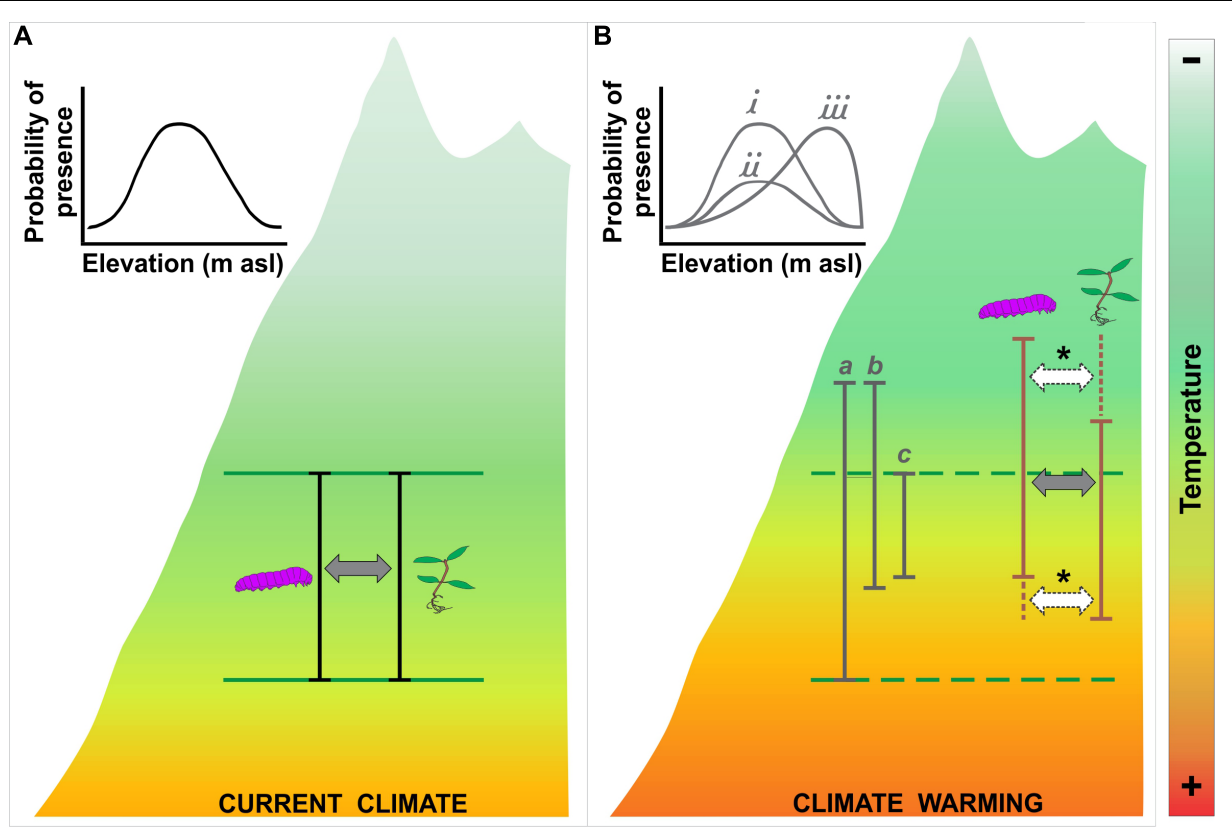

FIGURE 2 | Schematic representation of possible scenarios of species distribution changes in response to warming. The mountain is represented by the background figure and the color gradients represent the altitudinal variation in temperature. (A) Current conditions showing the range of distribution of a species (black bar and delimited by green lines) and the hypothetical probability of occurrence. (B) Possible changes in distribution and abundance patterns under climate change scenarios. Some hypotheses are: warming can lead to range expansion (a), shifts (b) or contractions (c), and probability of occurrence will likely remain stable (i), decrease over the range (ii) or move to the range margin (iii) (Feeley et al., 2012; Feeley, 2015; Peterson et al., 2019). On the right side, potential plant-animal (e.g., herbivores, pollinators, predators; represent by caterpillar) interaction partners mismatches $\left(^{*}\right)$ under asynchronous species migration scenarios are indicated.

and alter trophic interactions (Renner and Zohner, 2018; Boukal et al., 2019). Overall, little is known about how climate change will impact the role of consumers on host plants or as prey for predators (Tylianakis et al., 2008; Lurgi et al., 2012).

To explore how the responses of plants to climate change depend on the migration of other species, Alexander et al. (2015) transplanted alpine plant communities along an elevational gradient in the Swiss Alps. This study showed that the performance of plants growing under warmer climates (simulated through downslope transplants) is strongly reduced by new competitors that emerge through upward migrations. On the other hand, high-elevation competitors had little or no effect on the plants migrating upslope. Further similar experimental studies could enable us to better understand plant community responses to altered competitive interactions under climate change (Alexander et al., 2016) and address additional areas of uncertainty, such as priority effects (Fadrique and Feeley, 2016).

In the studies of Tito et al. (2018) and Tito Leon (2017), upslope migrations were simulated by growing plants in soils translocated from higher elevations (i.e., upward migrating plants will grow under their current climate but at higher elevations and thus in different soils) allowing them to test the effect of changing soil conditions on plant performance. The productivity of maize varieties significantly decreased in high-elevation soils due to changes in soil nutrients (including altered Ca:Mg concentrations) (Tito et al., 2018); in contrast, the survival and growth of seedlings of a dominant cloud forest tree species (Weinmannia bangii) were not affected by changes in soil
(Tito Leon, 2017). Understanding the potential effects of climate change on soil biota and on plant microbe interactions are other important areas of study where soil translocation experiments could provide valuable information. The vast majority of plant species are associated with soil microorganisms that are critical for the growth and establishment of plants, and for dictating plant community composition (Collins et al., 2016; Sayer et al., 2017). A greenhouse warming experiment revealed that changes in soil biota due higher temperatures negatively affected the competitive capacity of Poa trivialis, although in the absence of competitors it favored their growth (Cardinaux et al., 2018). Another recent study (Nottingham et al., 2019) that translocated soil monoliths along an elevation gradient in the Andes showed that warming caused shifts in microbial community composition and changes in microbial physiology leading to increased carbon use efficiency.

Several authors have suggested that local adaptation may play a key role in determining species' responses to warming (e.g., Peterson et al., 2018, 2019; Solarik et al., 2018); despite this, the possibility of local adaptation is often ignored or overlooked (Feeley, 2015; Peterson et al., 2019). Transplant experiments from different local populations within species' ranges can be used to study the influence of local adaptation on species' response to climate change. In their study of $W$. bangii, Tito Leon (2017) transplanted seedlings collected from the upper edge, middle and lower edge of the species' elevational/thermal range. These transplants revealed that the responses to warming varied between populations such that the mid-range populations 
were generally more sensitive to warming than the range-edge populations. This same study also showed that seedling survival increased with elevation. This suggests that the most favorable conditions for seedling survival of this species occur in areas near the upper limit of the current elevational range, contrary to expectation areas near to the middle of species' range should be the most favorable and that conditions should be more stressful near range limits (Holt, 2003; Sexton et al., 2009; Figure 2A). Overall, fine-scale experimental approaches such as these could help us to better predict the future abundances and distributions of species under altered climate scenarios, as well as the potential evolutionary responses of species (Verheyen et al., 2019). The possibility that the abundance patterns within species ranges could remain constant or shifted as species' ranges move, expand or contract (Figure 2B) under climate change (Feeley et al., 2012; Feeley, 2015; Peterson et al., 2019) also needs to be tested empirically.

\section{CONCLUSION}

There are many knowledge gaps and areas of uncertainty about how species will respond to current and future climate change. In particular, we know very little about how biotic interactions (e.g., between plants and their competitors, herbivores, pollinators, pathogens, and soil microbes) will be affected by altered climates and how these interactions will influence individual species and communities. The field experiment studies that have been

\section{REFERENCES}

Agosta, S. J., Hulshof, C. M., and Staats, E. G. (2017). Organismal responses to habitat change: herbivore performance, climate and leaf traits in regenerating tropical dry forests. J. Anim. Ecol. 86, 590-604. doi: 10.1111/1365-2656.12647

Alexander, J. M., Chalmandrier, L., Lenoir, J., Burgess, T. I., Essl, F., Haider, S., et al. (2018). Lags in the response of mountain plant communities to climate change. Glob. Change Biol. 24, 563-579. doi: 10.1111/gcb.13976

Alexander, J. M., Diez, J. M., Hart, S. P., and Levine, J. M. (2016). When climate reshuffles competitors: a call for experimental macroecology. Trends Ecol. Evol. 31, 831-841. doi: 10.1016/j.tree.2016.08.003

Alexander, J. M., Diez, J. M., and Levine, J. M. (2015). Novel competitors shape species' responses to climate change. Nature 525, 515-518. doi: 10.1038/ nature 14952

Antonelli, A., Kissling, W. D., Flantua, S. G. A., Bermúdez, M. A., Mulch, A., Muellner-Riehl, A. N., et al. (2018). Geological and climatic influences on mountain biodiversity. Nat. Geosci. 11, 718-725. doi: 10.1038/s41561-0180236-z

Barthlott, W., Lauer, W., and Placke, A. (1996). Global distribution of species diversity in vascular plants: towards a world map of phytodiversity. Erdkunde 50, 317-327. doi: 10.1127/1869-6155/2011/0129-0056

Beck, J., McCain, C. M., Axmacher, J. C., Ashton, L. A., Bärtschi, F., Brehm, G., et al. (2017). Elevational species richness gradients in a hyperdiverse insect taxon: a global meta-study on geometrid moths. Glob. Ecol. Biogeogr. 26, 412-424. doi: 10.1111 /geb. 12548

Bender, I. M. A., Kissling, W. D., Böhning-Gaese, K., Hensen, I., Kühn, I., Nowak, L., et al. (2019). Projected impacts of climate change on functional diversity of frugivorous birds along a tropical elevational gradient. Sci. Rep. 9:17708. doi: 10.1038/s41598-019-53409-6

Berg, M. P., Kiers, E. T., Driessen, G., van der Heijden, M., Kooi, B. W., Kuenen, F., et al. (2010). Adapt or disperse: understanding species persistence in a changing world. Glob. Change Biol. 16, 587-598. doi: 10.1111/j.1365-2486.2009.02014.x conducted to date indicate that transplant and translocation experiments along natural environmental gradients in mountain systems offer a very valuable, but underutilized, approach to study species' response to climate warming. We encourage future studies to take advantage of natural gradients to help us gain a more complete understanding of the possible impacts of climate change on species, communities and biodiversity.

\section{DATA AVAILABILITY STATEMENT}

Publicly available datasets were analyzed in this study. This data can be found here: http://www.scielo.org.pe/scielo.php?script= sci_arttext\&pid=S1727-99332015000200004.

\section{AUTHOR CONTRIBUTIONS}

RT conceived the idea. All authors contributed to the writing and editing of the manuscript.

\section{FUNDING}

Financial support was provided by the US National Science Foundation (DEB-1350125 to KF), the Federal University of Uberlândia (through its Graduate Program in Ecology and Conservation), and the Brazilian Council of Research and Scientific Development (CNPq grant 302588/2015-9 to HV).

Binzer, A., Brose, U., Curtsdotter, A., Eklöf, A., Rall, B. C., Riede, J. O., et al. (2011). The susceptibility of species to extinctions in model communities. Basic Appl. Ecol. 12, 590-599. doi: 10.1016/j.baae.2011.09.002

Bokhorst, S., Bjerke, J. W., Street, L. E., Callaghan, T. V., and Phoenix, G. K. (2011). Impacts of multiple extreme winter warming events on sub-Arctic heathland: phenology, reproduction, growth, and CO2 flux responses. Glob. Change Biol. 17, 2817-2830. doi: 10.1111/j.1365-2486.2011.02424.x

Boukal, D. S., Bideault, A., Carreira, B. M., and Sentis, A. (2019). Species interactions under climate change: connecting kinetic effects of temperature on individuals to community dynamics. Curr. Opin. Insect Sci. 35, 88-95. doi: 10.1016/j.cois.2019.06.014

Cardinaux, A., Hart, S. P., and Alexander, J. M. (2018). Do soil biota influence the outcome of novel interactions between plant competitors? J. Ecol. 106, 1853-1863. doi: 10.1111/1365-2745.13029

Chen, I. C., Hill, J. K., Ohlemüller, R., Roy, D., and Thomas, C. D. (2011). Rapid range shifts of species associated with high levels of climate warming. Science 333, 1024-1026. doi: 10.1126/science.1206432

Collins, C. G., Carey, C. J., Aronson, E. L., Kopp, C. W., and Diez, J. M. (2016). Direct and indirect effects of native range expansion on soil microbial community structure and function. J. Ecol. 104, 1271-1283. doi: 10.1111/13652745.12616

Condom, T., Rau, P., and Espinoza, J. C. (2011). Correction of TRMM 3B43 monthly precipitation data over the mountainous areas of Peru during the period 1998 - 2007. Hydrol. Process. 1933, 1924-1933. doi: 10.1002/hyp. 7949

Dehling, D. M., Töpfer, T., Schaefer, H. M., Jordano, P., Böhning-Gaese, K., and Schleuning, M. (2014). Functional relationships beyond species richness patterns: trait matching in plant-bird mutualisms across scales. Glob. Ecol. Biogeogr. 23, 1085-1093. doi: 10.1111/geb.12193

Dunn, R. R., Harris, N. C., Colwell, R. K., Koh, L. P., and Sodhi, N. S. (2009). The sixth mass coextinction: are most endangered species parasites and mutualists? Proc. R. Soc. B Biol. Sci. 276, 3037-3045. doi: 10.1098/rspb.2009.0413 
Elmendorf, S. C., Henry, G. H. R., Hollister, R. D., Fosaa, A. M., Gould, W. A., Hermanutz, L., et al. (2015). Corrections for Elmendorf et al., experiment, monitoring, and gradient methods used to infer climate change effects on plant communities yield consistent patterns. Proc. Natl. Acad. Sci. U.S.A. 112:E4156. doi: $10.1073 /$ pnas. 1511529112

Elsen, P. R., and Tingley, M. W. (2015). Global mountain topography and the fate of montane species under climate change. Nat. Clim. Change 5, 772-776. doi: $10.1038 /$ nclimate 2656

Ettinger, A., and Hillerislambers, J. (2017). Competition and facilitation may lead to asymmetric range shift dynamics with climate change. Glob. Change Biol. 23, 1-13. doi: $10.1111 / \mathrm{gcb} .13649$

Ettinger, A. K., Chuine, I., Cook, B. I., Dukes, J. S., Ellison, A. M., Johnston, M. R., et al. (2019). How do climate change experiments alter plot-scale climate? Ecol. Lett. 22, 748-763. doi: 10.1111/ele.13223

Ettinger, A. K., Ford, K. R., and HilleRisLambers, J. (2011). Climate determines upper, but not lower, altitudinal range limits of Pacific Northwest conifers. Ecology 92, 1323-1331. doi: 10.1890/10-1639.1

Fadrique, B., Báez, S., Duque, Á, Malizia, A., Blundo, C., Carilla, J., et al. (2018). Widespread but heterogeneous responses of Andean forests to climate change. Nature 564, 207-212. doi: 10.1038/s41586-018-0715-9

Fadrique, B., and Feeley, K. J. (2016). Commentary: novel competitors shape species' responses to climate change. Front. Ecol. Evol. 4:33. doi: 10.3389/fevo. 2016.00033

Farfan-Rios, W., Garcia-Cabrera, K., Salinas, N., Raurau-Quisiyupanqui, M. N., and Silman, M. R. (2015). Lista anotada de árboles y afines en los bosques montanos del sureste peruano: la importancia de seguir recolectando. Rev. Peru. Biol. 22, 145-174. doi: 10.15381/rpb.v22i2.11351

Feeley, K. J. (2015). Moving forward with species distributions. Am. J. Bot. 102, 173-175. doi: 10.3732/ajb.1400545

Feeley, K. J., Davies, S. J., Perez, R., Hubbell, S. P., and Foster, R. B. (2011a). Directional changes in the species composition of a tropical forest. Ecology 92, 871-882. doi: 10.1890/10-0724.1

Feeley, K. J., Silman, M. R., Bush, M. B., Farfan, W., Cabrera, K. G., Malhi, Y., et al. (2011b). Upslope migration of Andean trees. J. Biogeogr. 38, 783-791. doi: 10.1111/j.1365-2699.2010.02444.x

Feeley, K. J., Rehm, E. M., and Machovina, B. (2012). perspective: the responses of tropical forest species to global climate change: acclimate, adapt, migrate, or go extinct? Front. Biogeogr. 4:69-82. doi: 10.21425/F5FBG12621

Freeman, B. G., Scholer, M. N., Ruiz-Gutierrez, V., and Fitzpatrick, J. W. (2018). Climate change causes upslope shifts and mountaintop extirpations in a tropical bird community. Proc. Natl. Acad. Sci. U.S.A. 115, 11982-11987. doi: 10.1073/ pnas. 1804224115

Frenne, P., Graae, B. J., Rodríguez-Sánchez, F., Kolb, A., Chabrerie, O., Decocq, G., et al. (2013). Latitudinal gradients as natural laboratories to infer species' responses to temperature. J. Ecol. 101, 784-795. doi: 10.1111/1365-2745.12074

Galmán, A., Abdala-Roberts, L., Zhang, S., Berny-Mier, Y., Teran, J. C., Rasmann, S., et al. (2018). A global analysis of elevational gradients in leaf herbivory and its underlying drivers: effects of plant growth form, leaf habit and climatic correlates. J. Ecol. 106, 413-421. doi: 10.1111/1365-2745.12866

Girardin, C. A. J., Malhi, Y., Aragão, L. E. O. C., Mamani, M., Huaraca Huasco, W., Durand, L., et al. (2010). Net primary productivity allocation and cycling of carbon along a tropical forest elevational transect in the Peruvian Andes. Glob. Change Biol. 16, 3176-3192. doi: 10.1111/j.1365-2486.2010.02235.x

Hargreaves, A. L., Suárez, E., Mehltreter, K., Myers-Smith, I., Vanderplank, S. E., Slinn, H. L., et al. (2019). Seed predation increases from the arctic to the equator and from high to low elevations. Sci. Adv. 5:eaau4403. doi: 10.1126/sciadv. aau4403

Hillerislambers, J., Harsch, M. A., Ettinger, A. K., Ford, K. R., and Theobald, E. J. (2013). How will biotic interactions influence climate change-induced range shifts? Ann. N. Y. Acad. Sci. 1297, 112-125. doi: 10.1111/nyas.12182

Hobbs, R. J., Arico, S., Aronson, J., Baron, J. S., Bridgewater, P., Cramer, V. A., et al. (2006). Novel ecosystems: theoretical and management aspects of the new ecological world order. Glob. Ecol. Biogeogr. 15, 1-7. doi: 10.1111/j.1466-822X. 2006.00212.x

Hodkinson, I. D. (2005). Terrestrial insects along elevation gradients: species and community responses to altitude. Biol. Rev. 80, 489-513. doi: 10.1017/ S1464793105006767

Holt, R. D. (2003). On the evolutionary ecology of species' ranges. Evol. Ecol. Res. 5, 159-178.
Ibañez, I., Clark, J. S., Dietze, M. C., Feeley, K., Hersh, M., LaDeau, S., et al. (2006). Predicting biodiversity change: outside the climate envelope, beyong the Species-Area Curve. Ecology 87, 1896-1906. doi: 10.1890/0012-9658(2006) 87[1896:pbcotc]2.0.co;2

Kapos, V., Rhind, J., Edwards, M., Price, M. F., and Ravilious, C. (2000). "Developing a map of the world's mountain forests," in Forests in Sustainable Mountain Development: a State of Knowledge Report for 2000, eds M. F. Price and N. Butt (Wallingford: CABI), doi: 10.1079/9780851994468.0000

Kessler, M., Kluge, J., Hemp, A., and Ohlemüller, R. (2011). A global comparative analysis of elevational species richness patterns of ferns. Glob. Ecol. Biogeogr. 20, 868-880. doi: 10.1111/j.1466-8238.2011.00653.x

Kimball, B. A. (2016). Crop responses to elevated CO2 and interactions with $\mathrm{H} 2 \mathrm{O}$, N, and temperature. Curr. Opin. Plant Biol. 31, 36-43. doi: 10.1016/j.pbi.2016. 03.006

Körner, C. (2004). Mountain biodiversity, its causes and function. Ambio 13, $11-17$.

Körner, C. (2007). The use of 'altitude' in ecological research. Trends Ecol. Evol. 22, 569-574. doi: 10.1016/j.tree.2007.09.006

Körner, C., Jetz, W., Paulsen, J., Payne, D., Rudmann-Maurer, K., and Spehn, E. (2017). A global inventory of mountains for bio-geographical applications. Alp. Bot. 127, 1-15. doi: 10.1007/s00035-016-0182-6

Körner, C., Paulsen, J., and Spehn, E. M. (2011). A definition of mountains and their bioclimatic belts for global comparisons of biodiversity data. Alp. Bot. 121, 73-78. doi: 10.1007/s00035-011-0094-4

Lavergne, S., Mouquet, N., Thuiller, W., and Ronce, O. (2010). Biodiversity and climate change: integrating evolutionary and ecological responses of species and communities. Annu. Rev. Ecol. Evol. Syst. 41, 321-350. doi: 10.1146/annurevecolsys-102209-144628

Lenoir, J., and Svenning, J.-C. (2015). Climate-related range shifts - a global multidimensional synthesis and new research directions. Ecography 38, 15-28. doi: 10.1111/ecog.00967

Lurgi, M., López, B. C., and Montoya, J. M. (2012). Novel communities from climate change. Phil. Trans. R. Soc. B 367, 2913-2922. doi: 10.1098/rstb.2012. 0238

MacLean, S. A., and Beissinger, S. R. (2017). Species' traits as predictors of range shifts under contemporary climate change: a review and meta-analysis. Glob. Change Biol. 23, 4094-4105. doi: 10.1111/gcb.13736

Malhi, Y., Silman, M., Salinas, N., Bush, M., Meir, P., and Saatchi, S. (2010). Introduction: elevation gradients in the tropics: laboratories for ecosystem ecology and global change research. Glob. Change Biol. 16, 3171-3175. doi: 10.1111/j.1365-2486.2010.02323.x

McCain, C. M. (2005). Elevational gradients in diversity of small mammals. Ecology 86, 366-372. doi: 10.1890/03-3147

McCain, C. M., and Sanders, N. J. (2010). Metabolic theory and elevational diversity of vertebrate ectotherms. Ecology 91, 601-609. doi: 10.1890/090704.1

Metcalfe, D. B., Asner, G. P., Martin, R. E., Silva Espejo, J. E., Huasco, W. H., Farfán Amézquita, F. F., et al. (2014). Herbivory makes major contributions to ecosystem carbon and nutrient cycling in tropical forests. Ecol. Lett. 17, 324-332. doi: 10.1111/ele.12233

Meybeck, M., Green, P., and Vörösmarty, C. (2001). A new typology for mountains and other relief classes. Mt. Res. Dev. 21, 34-45. doi: 10.1659/0276-4741(2001) 021[0034:antfma]2.0.co;2

Myers, N., Mittermeier, R. A., Mittermeier, C. G., da Fonseca, G. A. B., and Kent, J. (2000). Biodiversity hotspots for conservation priorities. Nature 403, 853-858. doi: 10.1038/35002501

Nooten, S. S., Andrew, N. R., and Hughes, L. (2014). potential impacts of climate change on insect communities: a transplant experiment. PLoS One 9:e85987. doi: 10.1371/journal.pone.0085987

Nooten, S. S., and Hughes, L. (2014). Potential impacts of climate change on patterns of insect herbivory on understorey plant species: a transplant experiment. Austral Ecol. 39, 668-676. doi: 10.1111/aec.12129

Nooten, S. S., and Hughes, L. (2017). The power of the transplant: direct assessment of climate change impacts. Clim. Change 144, 237-255. doi: 10.1007/s10584017-2037-6

Nottingham, A. T., Bååth, E., Reischke, S., Salinas, N., and Meir, P. (2019). Adaptation of soil microbial growth to temperature: using a tropical elevation gradient to predict future changes. Glob. Change Biol. 25, 827-838. doi: 10.1111/ gcb. 14502 
Nottingham, A. T., Fierer, N., Turner, B. L., Whitaker, J., Ostle, N. J., McNamara, N. P., et al. (2018). Microbes follow Humboldt: temperature drives plant and soil microbial diversity patterns from the Amazon to the Andes. Ecology 99, 2455-2466. doi: 10.1002/ecy.2482

Pelini, S. L., Bowles, F. P., Ellison, A. M., Gotelli, N. J., Sanders, N. J., and Dunn, R. R. (2011). Heating up the forest: open-top chamber warming manipulation of arthropod communities at Harvard and Duke Forests. Methods Ecol. Evol. 2, 534-540. doi: 10.1111/j.2041-210X.2011.00100.x

Peterson, M. L., Doak, D. F., and Morris, W. F. (2018). Both life-history plasticity and local adaptation will shape range-wide responses to climate warming in the tundra plant Silene acaulis. Glob. Change Biol. 24, 1614-1625. doi: 10.1111/gcb. 13990

Peterson, M. L., Doak, D. F., and Morris, W. F. (2019). Incorporating local adaptation into forecasts of species' distribution and abundance under climate change. Glob. Change Biol. 25, 775-793. doi: 10.1111/gcb.14562

Pressey, R. L., Cabeza, M., Watts, M. E., Cowling, R. M., and Wilson, K. A. (2007). Conservation planning in a changing world. Trends Ecol. Evol. 22, 583-592. doi: $10.1016 /$ j.tree.2007.10.001

Price, M. F., Arnesen, T., Gløersen, E., and Metzger, M. J. (2019). Mapping mountain areas: learning from Global, European and Norwegian perspectives. J. Mt. Sci. 16, 1-15. doi: 10.1007/s11629-018-4916-3

Rahbek, C. (1995). The elevational gradient of species richness: a uniform pattern? Ecography 18, 200-205. doi: 10.1111/j.1600-0587.1995.tb00341.x

Rahbek, C., Borregaard, M. K., Antonelli, A., Colwell, R. K., Holt, B. G., Nogues-Bravo, D., et al. (2019a). Building mountain biodiversity: geological and evolutionary processes. Science 365, 1114-1119. doi: 10.1126/science.aax 0151

Rahbek, C., Borregaard, M. K., Colwell, R. K., Dalsgaard, B., Holt, B. G., MoruetaHolme, N., et al. (2019b). Humboldt's enigma: what causes global patterns of mountain biodiversity? Science 365, 1108-1113. doi: 10.1126/science.aax0149

Rapp, J., and Silman, M. (2012). Diurnal, seasonal, and altitudinal trends in microclimate across a tropical montane cloud forest. Clim. Res. 55, 17-32. doi: $10.3354 / \mathrm{cr} 01127$

Rapp, J. M. (2010). Climate Control on Plant Performance across an Andean Altitudinal Gradient. Dissertation, Winston Salem, NC: Wake Forest University.

Rasmann, S., Pellissier, L., Defossez, E., Jactel, H., and Kunstler, G. (2014). Climatedriven change in plant-insect interactions along elevation gradients. Funct. Ecol. 28, 46-54. doi: 10.1111/1365-2435.12135

Rehm, E. M., and Feeley, K. J. (2015). The inability of tropical cloud forest species to invade grasslands above treeline during climate change: potential explanations and consequences. Ecography 38, 1167-1175. doi: 10.1111/ecog.01050

Rehm, E. M., and Feeley, K. J. (2016). Many species risk mountain top extinction long before they reach the top. Front. Biogeogr. 8:e27788.

Renner, S. S., and Zohner, C. M. (2018). Climate change and phenological mismatch in trophic interactions among plants, insects, and vertebrates. Annu. Rev. Ecol. Evol. Syst. 49, 165-182. doi: 10.1146/annurev-ecolsys-110617062535

Reside, A. E., Butt, N., and Adams, V. M. (2018). Adapting systematic conservation planning for climate change. Biodivers. Conserv. 27, 1-29. doi: 10.1007/s10531017-1442-5

Roslin, T., Hardwick, B., Novotny, V., Petry, W. K., Andrew, N. R., Asmus, A., et al. (2017). Higher predation risk for insect prey at low latitudes and elevations. Science 356, 742-744. doi: 10.1126/science.aaj1631

Sayer, E. J., Oliver, A. E., Fridley, J. D., Askew, A. P., Mills, R. T. E., and Grime, J. P. (2017). Links between soil microbial communities and plant traits in a species-rich grassland under long-term climate change. Ecol. Evol. 7, 855-862. doi: 10.1002/ece3.2700

Sexton, J. P., Mcintyre, P. J., Angert, A. L., and Rice, K. J. (2009). Evolution and ecology of species range limits. Annu. Rev. Ecol. Syst. 40, 415-436. doi: 10.1146/annurev.ecolsys.110308.120317

Sheikh, M. A., Kumar, M., and Bussmann, R. W. (2009). Altitudinal variation in soil organic carbon stock in coniferous subtropical and broadleaf temperate forests in Garhwal himalaya. Carbon Balance Manag. 4:6. doi: 10.1186/17500680-4-6
Silveira, F. A. O., Barbosa, M., Beiroz, W., Callisto, M., Macedo, D. R., Morellato, L. P. C., et al. (2019). Tropical mountains as natural laboratories to study global changes: a long-term ecological research project in a megadiverse biodiversity hotspot. Perspect. Plant Ecol. Evol. Syst. 38, 64-73. doi: 10.1016/j.ppees.2019. 04.001

Solarik, K. A., Messier, C., Ouimet, R., Bergeron, Y., and Gravel, D. (2018). Local adaptation of trees at the range margins impacts range shifts in the face of climate change. Glob. Ecol. Biogeogr. 27, 1507-1519. doi: 10.1111/geb. 12829

Tito Leon, R. (2017). Respostas das plantas às mudanças climáticas em uma região andina do Perú - "Plant responses to climate change in an Andean region of Peru. Available online at: http://repositorio.ufu.br/handle/123456789/20981 (accessed October 2019).

Tito, R., Vasconcelos, H. L., and Feeley, K. J. (2018). Global climate change increases risk of crop yield losses and food insecurity in the tropical Andes. Glob. Change Biol. 24, e592-e602. doi: 10.1111/gcb.13959

Townsend, A. R., Vitousek, P. M., and Trumbore, S. E. (1995). Soil organic matter dynamics along gradients in temperature and land use on the Island of Hawaii. Ecology 76, 721-733. doi: 10.2307/1939339

Tylianakis, J. M., Didham, R. K., Bascompte, J., and Wardle, D. A. (2008). Global change and species interactions in terrestrial ecosystems. Ecol. Lett. 11, 13511363. doi: 10.1111/j.1461-0248.2008.01250.x

Valdés, A., Marteinsdóttir, B., and Ehrlén, J. (2018). A natural heating experiment: phenotypic and genotypic responses of plant phenology to geothermal soil warming. Glob. Change Biol. 25:gcb.14525. doi: 10.1111/gcb.14525

Verheyen, J., Tüzün, N., and Stoks, R. (2019). Using natural laboratories to study evolution to global warming: contrasting altitudinal, latitudinal, and urbanization gradients. Curr. Opin. Insect Sci. 35, 10-19. doi: 10.1016/j.cois. 2019.06.001

Vitousek, P. M., and Farrington, H. (1997). Nutrient limitation and soil development: experimental test of a biogeochemical theory. Biogeochemistry 37 , $63-75$.

Vitousek, P. M., and Sanford, R. L. (1986). Nutrient cycling in moist tropical forest. Annu. Rev. Ecol. Syst. 17, 137-167. doi: 10.1146/annurev.es.17.110186.001033

Wang, P., Limpens, J., Mommer, L., van Ruijven, J., Nauta, A. L., Berendse, F., et al. (2017). Above- and below-ground responses of four tundra plant functional types to deep soil heating and surface soil fertilization. J. Ecol. 105, 947-957. doi: 10.1111/1365-2745.12718

Wolkovich, E. M., Cook, B. I., Allen, J. M., Crimmins, T. M., Betancourt, J. L., Travers, S. E., et al. (2012). Warming experiments underpredict plant phenological responses to climate change. Nature 485, 494-497. doi: 10.1038/ nature11014

Xu, Z., Chang, Y., Li, L., Luo, Q., Xu, Z., Li, X., et al. (2019). Climatic and topographic variables control soil nitrogen, phosphorus, and nitrogen: phosphorus ratios in a Picea schrenkiana forest of the Tianshan Mountains. PLoS One 14:e0211839. doi: 10.1371/journal.pone.0211839

Yang, Y., Halbritter, A. H., Klanderud, K., Telford, R. J., Wang, G., and Vandvik, V. (2018). Transplants, open top chambers (OTCs) and gradient studies ask different questions in climate change effects studies. Front. Plant Sci. 9:1574. doi: $10.3389 /$ fpls.2018.01574

Zimmermann, M., Meir, P., Bird, M. I., Malhi, Y., and Ccahuana, A. J. Q. (2010). Temporal variation and climate dependence of soil respiration and its components along a $3000 \mathrm{~m}$ altitudinal tropical forest gradient. Glob. Biogeochem. Cycles 24, 1-13. doi: 10.1029/2010GB003787

Conflict of Interest: The authors declare that the research was conducted in the absence of any commercial or financial relationships that could be construed as a potential conflict of interest.

Copyright (C) 2020 Tito, Vasconcelos and Feeley. This is an open-access article distributed under the terms of the Creative Commons Attribution License (CC BY). The use, distribution or reproduction in other forums is permitted, provided the original author(s) and the copyright owner(s) are credited and that the original publication in this journal is cited, in accordance with accepted academic practice. No use, distribution or reproduction is permitted which does not comply with these terms. 